\title{
Hubungan Komunikasi Interpersonal dengan Kepuasan Kerja Pegawai di Dinas Pendidikan Kota Padang
}

Fitra Maya, Nellitawati ${ }^{2}$, Ahmad Sabandi ${ }^{3}$, Nelfia Adi ${ }^{4}$

1,2,3,4 Administrasi Pendidikan, Universitas Negeri Padang

Fitra Maya ${ }^{1}$, e-mail: fitramaya adm.pen@gmail.com

Nellitawati ${ }^{2}$, e-mail: nellitawati@fip.unp.ac.id

Ahmad Sabandi ${ }^{3}$, e-mail: sabandi@fip.unp.ac.id

Nelfia Adi ${ }^{4}$, e-mail: nelfia adi@fip.ac.id

\begin{abstract}
The purpose of this research is to obtain information about the relationship between interpersonal communication and job satisfaction of employees at the Padang City Education Office from the point of view of openness, empathy, support, equality, and positive attitudes (variable $\mathrm{X}$ ) and likes to work, enthusiastic at work, and not. protest at work (variable Y). All employees of Padang City Education Office are the population in this study, amounting to 117 people with a sample of 54 employees. The instrument uses a Likert scale questionnaire which has been tested to observe the validity and reliability of the questionnaire. This data is analyzed using the mean (average) formula. The results of this research are the relationship between interpersonal communication and job satisfaction of employees at Padang City Education Office seen from the value (1) like to work with a score of 31.3 (2) enthusiastic at work with a score of 62.2 (3) do not protest at work with a score of 30,8 (variable Y) and (1) openness with a score of 22.18 (2) empathy with a score of 22.44 (3) support with a score of 26.16 (4) similarity with a score of 30.1 (5) a positive attitude with a score 27.1 (variable X). The conclusion is that there is no relationship between interpersonal communication and job satisfaction of employees at Padang City Education Office.
\end{abstract}

\begin{abstract}
Abstrak
Tujuan riset ini untuk memperoleh informasi mengenai kontribusi komunikasi interpersonal dengan puas dalam bekerja di Dinas Pendidikan Kota yang dilihat dari sudut pandang keterbukaan, empati, dukungan, kesamaan, dan sikap positif (variabel X) dan suka dalam bekerja, antusias dalam bekerja, serta tidak protes dalam bekerja (variabel Y). Seluruh pegawai Dinas Pendidikan Kota Padang menjadi populasi pada penelitian ini yang sebanyak 117 pegawai dengan sampel sebanyak 54 pegawai. Instrumen menggunakan kuesioner skala Likert yang telah dites untuk mengamati validitas serta reliabilitas angket. Data ini dianalisis dengan menggunakan rumus mean (rata-rata). Hasil riset ini yaitu kontribusi komunikasi interpersonal dengan puas bekerja di Dinas Pendidikan Kota Padang dilihat dari nilai (1) suka dalam bekerja dengan skor 31,3 (2) antusias dalam bekerja dengan skor 62,2 (3) tidak protes dalam bekerja dengan skor 30,8 (variabel Y) dan (1) keterbukaan dengan skor 22,18 (2) empati dengan skor 22,44 (3) dukungan dengan skor 26,16 (4) kesamaan dengan skor 30,1 (5) sikap positif dengan skor 27,1 (variabel X). Kesimpulannya adalah tidak ada kontribusi komunikasi interpersonal dengan puas dalam bekerja di Dinas Pendidikan Kota Padang.
\end{abstract}

Kata Kunci: Kepuasan Kerja Pegawai, Komunikasi Interpersonal

How to Cite: Fitramaya 1, Nellitawati 2, Ahmad Sabandi 3, Nelfia Adi 4. 2021. Hubungan Komunikasi Interpersonal dengan Kepuasan Kerja Pegawai di Dinas Pendidikan Kota Padang. Journal Educational Administration and Leadership, Vol (N): pp. XX-XX, DOI: 10.24036/XXXXXXXXXX-X-XX

This is an open access distributed under the Creative Commons 4.0 Attribution License, which permits unrestricted use, distribution, and reproduction in any medium, provided the original work is properly cited. (C2021 by author.

\section{Pendahuluan}

Seorang pegawai merasa kurang suka dalam lingkungan kerja, hal ini berpengaruh terhadap kepuasan kerja seseorang. Menurut (Gusliza, 2013) pegawai ialah seorang individu yang mempunyai pandangan, keyakinan, 
serta kemauan dapat mendorong sikap pegawai yang berhubungan dengan pekerjaannya. perilaku tersebut akan menentukan kinerja, kontribusi serta kesenangan pegawai terhadap pekerjaan. Perilaku yang ada pada pegawai adalah sikap baik serta tidak baik. Perilaku baik pegawai sebaiknya diterapkan, sementara perilaku tidak baik pada pegawai harus dihapuskan. Perilaku positif pada pegawai dikatakan dengan puas dalam bekerja. (Spector, 2016) berpendapat bahwa puas dalam bekerja adalah seperti apa tanggapan yang selayaknya pada pegawai berhubungan dengan tugas serta sudut pandang terhadap tugas tersebut. Puas dalam bekerja adalah pegawai menyenangi atau tidak menyenangi pekerjaannya. Ketika pegawai menyenangi tugas yang diamanahkan kepadanya produktivitas kerja bertambah. namun, jika pegawai tidak menyenangi tugasnya tidak diperoleh hasil kinerja yang baik sehingga kejadian ini akan berdampak buruk terhadap organisasi. Hal ini didukung (Handoko, 2016) puas dalam bekerja menggambarkan bagaimana sikap suka atau tidak suka dengan tugasnya.

Puas dalam bekerja adalah suatu sikap suka seseorang terhadap tugas yang dikerjakan sebagai penentu bagi seorang pegawai untuk (Muhammad, 2011)menumbuhkan hasil kerjanya. Dari hasil tinjauan dan wawancara yang penulis lakukan saat melaksanakan Praktek Lapangan Manajemen Pendidikan di Dispen Kota Padang mulai 02 Desember 2019 sampai 15 Februari 2020, bahwa masih rendah rasa puas pegawai dalam bekerja dilihat dari gejala-gejala berikut ini: 1) Beberapa pegawai menilai pekerjaan yang mereka lakukan kurang menyenangkan, hal ini ditandai dengan sering terlambatnya pegawai masuk kantor. Bahkan menurut informasi yang didapat beberapa pegawai meninggalkan ruangan pada jam kerja. 2) Masih ada sebagian pegawai yang tidak lega atau puas dalam menyelesaikan tugasnya. Ditandai adanya rasa cemas karena hasil yang diperoleh tidak sesuai dengan harapan. 3) Sebagian pegawai yang kurang bergairah dalam mengerjakan tugas yang diperintahkan oleh pemimpin. Dilihat dari kebiasaan pegawai menyelesaikan tugas yang cenderung lamban.

Adapun faktor yang mempengaruhi puas dalam bekerja bermacam ragam sebagai berikut: perbedaan personal, umur, kedudukan, instansi, administrasi, pengawasan langsung, relasi, gaji, lingkungan kerja (Suprayetno, 2016). Dari penjelasan diatas maka penulis memilih salah satu dari sebagian aspek mempengaruhi puas dalam kerja adalah hubungan interpersonal. dengan hubungan interpersonal bagus dapat meningkatkan kepuasan kerja. Hal yang mendasari pentingnya komunikasi untuk menangani rasa tidak senang dalam kerja dapat dibuat dengan menyampaikan pengetahuan yang lengkap kepada pegawai sehingga pegawai dapat melaksanakan tugas dengan maksimal serta ada perasaan puas dengan hasil yang diperoleh (Muhammad, 2011). Untuk kelangsungan suatu organisasi sangat membutuhkan yang namanya komunikasi (Nellitawati, 2019). Dari peninjauan penulis, dilihat bahwa hubungan komunikasi interpersonal yang terjadi antara pegawai dan pegawai, pegawai dan pimpinan kurang baik. Hal ini terlihat dari gejala-gejala berikut ini. 1) ketua kurang jelas menyampaikan informasi kepada pegawai terkait tugas yang diberikan. 2) Tidak terjalin kehangatan sesama pegawai serta pegawai dengan pemimpin. 3) Kurangnya rasa empati sesama pegawai, terlihat sebagian pegawai masih ada membedakan kedudukan dalam hubungan serta kerja sama di lingkungan instansi. 4) Adanya sebagian orang yang kurang menghargai pendapat dari pegawai lainnya. 5) Masih ada sebagian pegawai yang tidak memperdulikan pegawai lain ketika rekan kerjanya mendapat kesulitan maupun memperoleh suatu penghargaan seperti kenaikan pangkat dan promosi jabatan. 6) Kurangnya toleransi sesama pegawai. Dilihat dari masih ada beberapa orang yang tidak mengeluarkan pendapatnya di dalam rapat apabila ada opini yang kurang cocok terhadap pandangan pegawai.

Apabila masalah diatas dibiarkan terus menerus seperti itu maka dapat mengakibatkan cacat bagi perkembangan instansi. Maka penulis ingin meneliti tentang: kontribusi komunikasi interpersonal dengan puas dalam bekerja di Dinas Pendidikan Kota Padang.

\section{Metode Penelitian}

Riset dikategorikan ke dalam jenis korelasional dengan menggunakan metode kuantitatif. Riset ini bertujuan untuk melihat kesesuaian antara hubungan interpersonal dengan puas dalam bekerja di Dinas Pendidikan Kota Padang. Adapun populasi riset ini seluruh pegawai Dinas Pendidikan Kota Padang berjumlah 117 pegawai, sedangkan jumlah sampel adalah 54 orang pegawai. Instrumen yang digunakan dalam riset ini ialah angket atau kuesioner yang menggunakan skala likert sudah diuji coba validitas serta reliabilitasnya. Selanjutnya untuk mengumpulkan informasi dapat melakukan penyebaran angket, data riset diselesaikan menggunakan nilai rata-rata, modus, nilai tengah, serta DV. Selanjutnya melakukan pengujian normalitas serta pengujian koefisien memakai teknik uji Kolmogorov-Smirnov Test menemukan kaitan antara dua variabel, selanjutnya mengukur signifikan hubungan melalui bantuan komputer aplikasi data statistik SPSS 20.0.

\section{Hasil dan Pembahasan}

3.1. Hasil

\section{Kepuasan Kerja}

Pengolahan data variabel puas dalam bekerja (X) didapat dari menyebarkan angket sebanyak 54 pegawai serta 28 item pernyataan. Puas dalam bekerja menyebar dari nilai terendah 89 serta nilai tertinggi 139. Sementara nilai minimal adalah 28 serta nilai maksimal ialah 140. Kesimpulan olahan nilai keseluruhan diperoleh nilai rata-rata $($ mean $)=124,39$, median $=126,5$, modus $=129$, serta DV $=10,498$. 
penyebaran penyaluran data variabel puas dalam bekerja di Dinas Pendidikan Kota Padang disebut berdistribusi normal.

Terdapat 31,5\% responden yang memiliki kepuasan kerja rata-rata, 29,9\% responden memiliki puas dalam bekerja di atas rata-rata, selanjutnya sisanya sebesar 38,8\% pegawai merasa puas dalam bekerja di bawah rata-rata. Berdasarkan olahan angket variabel puas dalam bekerja dengan aturan membandingkan rata-rata dengan nilai maksimal dikali $100 \%$.

\begin{tabular}{|c|c|c|c|}
\hline Kelas Interval & $f$ & \% Frekuensi Absolut & $\begin{array}{c}\text { Frekuensi } \\
\text { Cumulative (\%) }\end{array}$ \\
\hline $83-90$ & 1 & 1,8 & 1,8 \\
\hline $91-98$ & 0 & 0 & 1,8 \\
\hline $99-106$ & 1 & 1,8 & 3,6 \\
\hline $107-114$ & 7 & 13 & 16,6 \\
\hline $115-122$ & 12 & 22,2 & 38,8 \\
\hline $123-130$ & 17 & 31,5 & 70,3 \\
\hline $131-138$ & 14 & 26 & 96,3 \\
\hline $139-146$ & 2 & 3,7 & 100 \\
\hline Jumlah & $\mathbf{5 4}$ & $\mathbf{1 0 0} \%$ & \\
\hline
\end{tabular}

Tabel 1. Distribusi Frekuensi Skor Variabel Kepuasan Kerja

Tabel 2. Rata-rata Tingkat Pencapaian Per Indikator Variabel Kepuasan Kerja

\begin{tabular}{|c|l|c|c|c|}
\hline No & \multicolumn{1}{|c|}{ Indikator } & Rata-rata & Tingkat Pencapaian & Kategori \\
\hline 1 & Senang & 31,3 & $\mathbf{8 9 \%}$ & Tinggi \\
\hline 2 & Semangat & 62,2 & $\mathbf{8 9 \%}$ & Tinggi \\
\hline 3 & Tidak Mengeluh & 30,8 & $\mathbf{8 9 \%}$ & Tinggi \\
\hline \multicolumn{2}{|l|}{ Rata-rata Total } & $\mathbf{1 2 4 , 3}$ & $\mathbf{8 9 \%}$ & Tinggi \\
\hline
\end{tabular}

Hasil olahan data didapat dari pegawai selanjutnya perbandingan rata-rata pada skor paling tinggi dikali $100 \%$ maka didapatkan skor menyeluruh puas dalam bekerja di Dispen Kota Padang pada posisi kategori "tinggi" dengan persentase sebesar $89 \%$. Selanjutnya pada setiap penanda dari suka dengan tugas rata-rata sebesar 31,3 posisi tinggi pada perolehan $89 \%$, penanda antusias pada tugas rata-rata ialah 62,2 berada pada kategori tinggi dengan perolehan $89 \%$, serta indikator tidak protes dalam bekerja rata-rata ialah 30,8 berada pada kategori tinggi dengan perolehan $89 \%$.

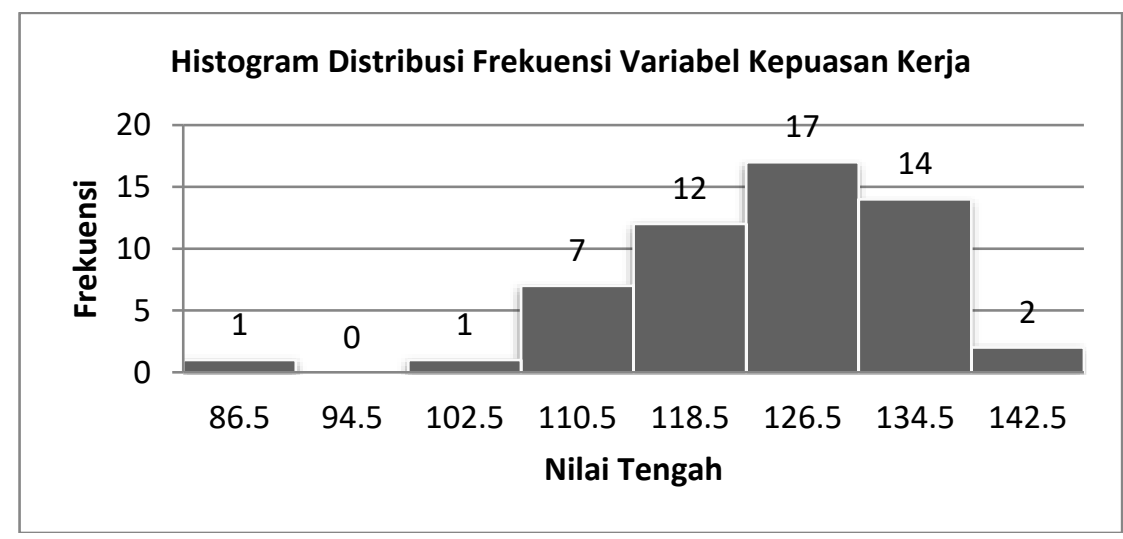

Gambar 1. Histogram Distribusi Frekuensi Variabel Kepuasan Kerja

\section{Komunikasi Interpersonal}

Hasil dari olahan data variabel komunikasi interpersonal diperoleh dari penyebaran angket terhitung 54 pegawai serta 30 item pernyataan. Komunikasi interpersonal menyebar mulai skor terendah 106 dan skor tertinggi 147. Sementara nilai minimal adalah 30 serta skor maksimal ialah 150. Kesimpulan pencarian nilai secara menyeluruh didapat nilai rata-rata $($ mean $)=127,9$, modus $=125$, median $=133$, dan standar deviasi $(D V)=8,376$. Penyebaran frekuensi data variabel komunikasi interpersonal di Dinas Pendidikan Kota Padang disebut berdistribusi normal. 
Tabel 3. Distribusi Frekuensi Skor Variabel Komunikasi Interpersonal

\begin{tabular}{|c|c|c|c|}
\hline Kelas Interval & $f$ & \% Frekuensi Absolut & $\begin{array}{c}\text { Frekuensi } \\
\text { kumulatif }\end{array}$ \\
\hline $106-111$ & 1 & $1,9 \%$ & $1,9 \%$ \\
\hline $112-117$ & 1 & $1,9 \%$ & $3,8 \%$ \\
\hline $118-123$ & 6 & $11,1 \%$ & $14,9 \%$ \\
\hline $124-129$ & 10 & $18,5 \%$ & $33,4 \%$ \\
\hline $130-135$ & 16 & $29,6 \%$ & $63 \%$ \\
\hline $136-141$ & 14 & $25,9 \%$ & $88,9 \%$ \\
\hline $142-147$ & 6 & $11,1 \%$ & $100 \%$ \\
\hline Jumlah & $\mathbf{5 4}$ & $\mathbf{1 0 0} \%$ & \\
\hline
\end{tabular}

Tabel 4. Rata-rata Tingkat Pencapaian Per Indikator Variabel Komunikasi Interpersonal

\begin{tabular}{|l|l|l|l|l|}
\hline No & Indikator & Rata-Rata & $\begin{array}{l}\text { Tingkat } \\
\text { Pencapaian }\end{array}$ & Kategori \\
\hline 1 & Keterbukaan & 22,18 & $74 \%$ & Cukup Baik \\
\hline 2 & Empati & 22,44 & $90 \%$ & Sangat Baik \\
\hline 3 & Dukungan & 26,16 & $87 \%$ & Baik \\
\hline 4 & Kesamaan & 30,1 & $86 \%$ & Baik \\
\hline 5 & Sikap Positif & 27,1 & $90 \%$ & Sangat Baik \\
\hline Rata-rata total & $\mathbf{1 2 7 , 9 8}$ & $\mathbf{8 5 \%}$ & Baik \\
\hline
\end{tabular}

Terdapat 29,6\% responden memiliki komunikasi interpersonal rata-rata, 33,4\% pegawai terletak pada hubungan interpersonal di atas rata-rata, sementara sisanya berjumlah $37 \%$ memiliki komunikasi interpersonal dibawah rata-rata. Berdasarkan olahan angket variabel komunikasi interpersonal dengan aturan membandingkan nilai rata-rata pada nilai paling tinggi dikali $100 \%$. Diperoleh nilai rata-rata keseluruhan variabel komunikasi interpersonal di Dispen Kota Padang pada posisi "baik" dengan pencapaian persentase $85 \%$. Setiap indikator mulai dari keterbukaan didasarkan pada perolehan nilai ratarata sejumlah 22,18 pada posisi cukup pada pencapaian $74 \%$, indikator empati dengan rata-rata sejumlah 22,4 berada pada kategori sangat baik dengan pencapaian $90 \%$, indikator dukungan nilai rata-rata sebanyak 26,16 berada pada kategori baik dengan pencapaian $87 \%$, indikator kesamaan dengan rata-rata ialah 30,1 pada posisi baik dengan pencapaian $86 \%$, serta pada indikator sikap positif nilai rata-rata ialah 27,1 berada pada kategori sangat baik dengan pencapaian $90 \%$.

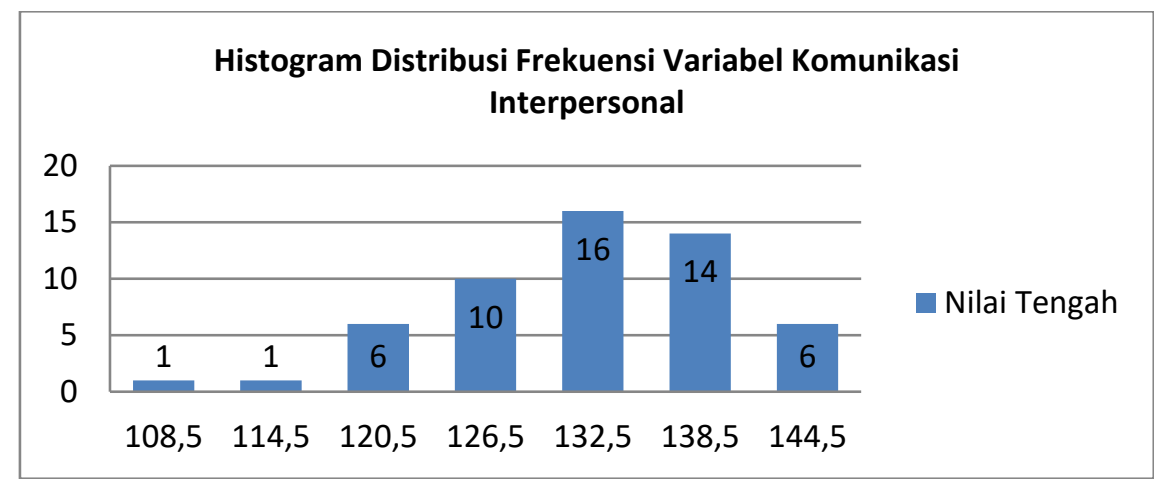

Gambar 3. Histogram Distribusi Frekuensi Variabel Komunikasi Interpersonal

\begin{tabular}{|c|l|c|c|c|}
\hline No & \multicolumn{1}{|c|}{ Variabel } & Mean & $\begin{array}{c}\text { \% Tingkat } \\
\text { Pencapaian }\end{array}$ & Interpretasi \\
\hline 1 & Kepuasan Kerja (Y) & 124,3 & 89 & Tinggi \\
\hline 2 & Komunikasi Interpersonal (X) & 127,98 & 85 & Baik \\
\hline
\end{tabular}

Tabel 1. Rangkuman Hasil Penelitian 


\subsection{Hubungan Interpersonal dengan Puas Dalam Bekerja di Dinas Pendidikan Kota Padang}

Berdasarkan hasil uji korelasi antara variabel komunikasi interpersonal dengan variabel puas dalam bekerja, maka diperoleh nilai signifikansinya adalah 0,251 pada taraf signifikansi $5 \%$ atau pada taraf kepercayaan 95\%, dari perhitungan uji korelasi tersebut, 0,251 lebih besar dari 0,005. Kriteria dalam pengujian hipotesis menyatakan jika hasil signifikansinya lebih besar dari 0,251 , maka tidak terdapat korelasi atau hubungan antara variabel komunikasi interpersonal dengan puas dalam bekerja di Dinas Pendidikan Kota Padang. Dapat ditarik kesimpulan bahwa tidak ada hubungan antara variabel interpersonal dengan puas dalam bekerja di Dinas Pendidikan Kota Padang.

\begin{tabular}{|ll|r|r|}
\hline \multicolumn{1}{|c|}{ Correlations } & \multicolumn{1}{c|}{$\begin{array}{c}\text { Kepuasan } \\
\text { Kerja }\end{array}$} \\
\hline Komunikasi Interpersonal & Kearson Correlation & 1 & -.159 \\
& Sig. (2-tailed) & & .251 \\
& $\mathrm{~N}$ & 54 & 54 \\
\hline Kepuasan Kerja & Pearson Correlation & & \\
& Sig. (2-tailed) & -.159 & 1 \\
& $\mathrm{~N}$ & & .251 \\
& & 54 & 54 \\
\hline
\end{tabular}

\subsection{Pembahasan}

\section{Kepuasan Kerja Pegawai}

pengolahan angket didapatkan dari pegawai diketahui bahwa puas dalam bekerja di Dispen Kota Padang pada posisi tinggi dengan pencapaian $89 \%$. Maka puas dalam bekerja di Dinas Pendidikan Kota Padang disebut sudah baik, walaupun begitu pimpinan perlu meningkatkan perhatian dan hubungan atau relasi yang harmonis dengan pegawai sehingga terjalin hubungan dan lingkungan kerja yang kondusif.

\section{Komunikasi Interpersonal}

Dari hasil pengolahan data yang diperoleh dari responden dapat diketahui bahwa komunikasi interpersonal di Dinas Pendidikan Kota Padang berada pada kategori baik dengan tingkat pencapaian nilai ideal 85\%. Maka komunikasi interpersonal di Dinas Pendidikan Kota Padang dapat dikatakan sudah baik dan perlu ditingkatkan lagi agar mencapai komunikasi interpersonal yang baik.

Hasil riset uji hipotesis yang berhubungan dengan komunikasi interpersonal dengan puas dalam bekerja di Dinas Pendidikan Kota Padang kesimpulan berikut ini: 1) puas dalam bekerja di Dinas Pendidikan Kota Padang pada posisi tinggi terhadap tugas dapat dilihat dari perolehan hasil analisis data sebanyak 89\%, 2) Komunikasi interpersonal di Dispen Kota Padang pada posisi baik terhadap tugas dilihat perolehan hasil dari analisis data sebanyak 85\%. 3) Tidak ada hubungan antara variabel komunikasi interpersonal dengan variabel puas dalam bekerja di Dinas Pendidikan Kota Padang. Perhitungan hasil uji korelasi antara variabel komunikasi interpersonal dengan variabel puas dalam bekerja, maka diperoleh nilai signifikansinya adalah 0,251 pada taraf $5 \%$ atau taraf kepercayaan $95 \%$. Dari hasil perhitungan uji korelasi tersebut, 0,251 lebih besar dari 0,005 . Kriteria dalam pengujian hipotesis menyatakan bahwa jika hasil signifikansinya lebih besar dari 0,005 , maka tidak terdapat hubungan yang signifikan atau korelasi antara kedua variabel. Hasil dari perolehan data menyeluruh penulis dapat menyimpulkan tidak ada hubungan yang antara variabel komunikasi interpersonal dengan variabel puas dalam bekerja di Dispen Kota Padang.

\section{Kesimpulan}

Perolehan hasil riset serta uji hipotesis kontribusi hubungan interpersonal dengan puas dalam bekerja di Dinas Pendidikan Kota Padang dapat simpulkan: 1) puas dalam bekerja di Dinas Pendidikan Kota Padang terletak pada posisi tinggi terhadap tugas dilihat dari perolehan hasil analisis data sebanyak 89\%, 2) Hubungan interpersonal di Dispen Kota Padang posisi baik pada tugas dilihat dari perolehan hasil analisis data sebesar $85 \%, 3)$ Tidak ada kaitan yang signifikan antara komunikasi interpersonal dengan puas dalam bekerja di Dinas Pendidikan Kota Padang. Sama halnya pendapatan pengujian coba korelasi pada variabel kepuasan kerja (Y) diperoleh hasil Asymp. Sig. (2-tailed) adalah 0,065 dengan taraf signifikansi 0,005. Jadi nilai 0,065> dari 0,005, maka data tersebut berdistribusi normal. Sedangkan pada variabel komunikasi interpersonal (X) diperoleh hasil 
Asymp. Sig. (2-tailed) adalah 0,200 dengan taraf nilai signifikansinya adalah 0,005. Jadi nilai 0,200 > dari 0,005 , maka data tersebut berdistribusi normal.

\section{Daftar Rujukan}

Gusliza. (2013). Hubungan Komunikasi Interpersonal dengan Kepuasan Kerja Pegawai di Dinas Pendidikan Pemuda dan Olahraga Kota Bukittinggi. Jurnal Bahana Manajemen Pendidikan.

Handoko. (2016). Pengaruh Kepuasan Kerja Terhadap Produktivitas Kerja Pegawai BANK Syariah X Kantor II. Jurnal Manajemen Dan Pemasaran Jasa.

Muhammad. (2011). Komunikasi Organisasi. Jakarta: Bumi Aksara.

Nellitawati. (2019). Interpersonal Communication Relationship With Employee Job Satisfaction. Journal Education.

Spector. (2016). Pengaruh Organizational Support Terhadap Job Satisfaction Tenaga Educatif Tetap Fakultas Ekonomi dan Bisnis Universitas Tri Sakti. Jurnal Manajemen Dan Pemasaran Jasa.

Suprayetno. (2016). Pengaruh Motivasi Kerja, Kepemimpinan dan Budaya Organisasi Terhadap Kepuasan Kerja Karyawan Serta Dampaknya Pada Perusahaan. Jurnal Manajemen dan Kewirausahaan. 